\title{
Development of a Sensitive TaqMan qPCR Assay for Detection and Quantification of Venturia inaequalis in Apple Leaves and Fruit and in Air Samples
}

\author{
Simona Prencipe, ${ }^{1}$ Fabiano Sillo, ${ }^{1}$ Angelo Garibaldi, ${ }^{2}$ Maria Lodovica Gullino, ${ }^{1,2}$ and Davide Spadaro ${ }^{1,2, \dagger}$ \\ ${ }^{1}$ Department of Agricultural, Forestry and Food Sciences (DiSAFA), University of Torino, via Paolo Braccini 2, 10095, Gru- \\ gliasco, Italy \\ 2 Centre of Competence for the Innovation in the Agro-environmental Sector-AGROINNOVA, University of Turin, via Paolo \\ Braccini 2, 10095, Grugliasco, Italy
}

\begin{abstract}
A TaqMan quantitative PCR (qPCR) assay based on the translation elongation factor $1-\alpha$ gene was developed for the quantification of Venturia inaequalis in leaves and fruits of Malus $\times$ domestica and in spore trap samples. The designed primers and hydrolysis probe amplified a specific 86-bp fragment for $V$. inaequalis. The specificity of the assay was tested using 35 strains of $V$. inaequalis and 20 different fungal species, including common pathogens of apple and other species of Venturia. The limit of detection was $20 \mathrm{fg}$, which is lower than a single genome of $V$. inaequalis. The selectivity of the assay was tested using DNA from three cultivars of Malus $\times$ domestica, and no influence on pathogen amplification was found. The assay was also validated for re-

leaves and in symptomatic Golden Delicious apple fruit stored for 2 months. Furthermore, the assay was successfully tested on spore trap samples originating from apple orchards. The quantification of the molecular assay when compared with the estimated number of $V$. inaequalis cells, using an optical microscope, showed a correlation coefficient of 0.8186 . The developed technique could be used to detect $V$. inaequalis in asymptomatic samples without any cross-reaction with other fungal species. Furthermore, to improve the efficacy of disease management with a timely application of fungicides, this assay could be used for the analysis of spore trap samples by using an implemented extraction method.
\end{abstract} peatability and reproducibility. With this assay, it was possible to detect and quantify $V$. inaequalis in four cultivars (Ambrosia, Florina, Golden Delicious, and Mondial Gala) in both symptomatic and asymptomatic
Keywords: apple scab, Malus $\times$ domestica, real-time PCR, TaqMan, Venturia inaequalis
Apple scab is a worldwide disease of apple (Malus $\times$ domestica Bork H.) caused by the ascomycete Venturia inaequalis (Cooke) G. Winter (Sutton et al. 2014). The disease is particularly severe in temperate climate regions characterized by humid and cool springs (Bowen et al. 2011) and, if not appropriately managed, can cause huge economic losses (MacHardy 1996). Disease control requires an integrated strategy based on prophylactic practices, application of fungicides, and increasing the use of resistant cultivars (MacHardy et al. 2001).

$V$. inaequalis has a hemibiotrophic life cycle. Ascospores, which are released from pseudothecia in the fallen leaves, cause primary infections during the growing season (spring to early summer). If the weather conditions are favorable, asexual conidia are released and cause secondary infections during the growing season (Bowen et al. 2011; Carisse et al. 2000). The entire life cycle of $V$. inaequalis

Current address for F. Sillo: National Research Council-Institute for Sustainable Plant Protection (CNR-IPSP), 10125 Torino, Italy

${ }^{\dagger}$ Corresponding author: D. Spadaro; davide.spadaro@unito.it

Funding: The authors thank Fondazione Cassa di Risparmio di Cuneo for its financial support through the projects "FRUITSENSOR-Converging technologies for sustainable precision fruit-growing", "SMART APPLE-Innovative and SMART technologies for sustainable APPLE production" and EIT Food, supported by EIT, a body of the the European Union, for funding the KAVA 20152 "CLEANFRUIT" -Standardization of innovative pest control strategies to produce zero residue fruit for baby food and other fruit produce.

*The $\boldsymbol{e}$-Xtra logo stands for "electronic extra" and indicates there are supplementary materials published online.

The author(s) declare no conflict of interest.

Accepted for publication 19 May 2020.

(C) 2020 The American Phytopathological Society is strongly influenced by humidity and temperature conditions (MacHardy 1996). In order to reduce scab infections, fungicide application programs are scheduled based on the local weather conditions, on disease prediction models, and on the level of infection in spy plants (Carisse et al. 2000; Gadoury and MacHardy 1986; Meitz-Hopkins et al. 2014; Mills and Laplante 1951). Spy plants are apple plants potted with a mulching of diseased leaves, which are exposed in orchard to a single rain until the end of leaf wetness. These plants permit an a posteriori evaluation to identify the first infection period for $V$. inaequalis (Rizzolli and Acler 2010).

In the field, the level of apple scab infection is normally estimated by visually assessing the symptoms and assigning a score (Bock et al. 2010; Gusberti et al. 2012). However, the observation of disease symptoms does not always reflect the real pathogen colonization (Gu et al. 2011; Shaw et al. 2010). Furthermore, the lesion development rate, related to leaf age and fungicide treatments, could underestimate the severity of the disease and lead to incorrect crop protection programs (Keitt and Jones 1926; Li and $\mathrm{Xu}$ 2002; Schwabe 1979). In addition, through the use of visual scoring as a diagnostic method, no information is acquired from asymptomatic leaves, important sources for both primary and secondary infections.

Molecular techniques have the advantages of being sensitive, specific, not biased by the operator and could be also used on asymptomatic tissues. Different studies have been reported for specific detection of $V$. inaequalis using conventional PCR (Koh et al. 2013; Schnabel et al. 1999; Stehmann et al. 2001) or, recently, LAMP (Prencipe et al. 2020). Daniëls et al. (2012) developed a quantitative real-time PCR (qPCR) assay targeting the internal transcribed spacer (ITS), while Gusberti et al. (2012) developed a qPCR assay based on primers and hydrolysis probe designed on the housekeeping gene ABC2 (ATPbinding cassette transporter 2 ) to detect $V$. inaequalis. Nevertheless, in a study ny Gusberti et al. (2012), the specificity of the assay was not tested against other fungal species to avoid cross-reactions, resulting in the possibility of false-positive results and pathogen overestimation. A blast analysis of the primers and hydrolysis probes used by Gusberti et al. (2012) was performed in our laboratory. The search 
gave $100 \%$ homology and $100 \%$ coverage with Alternaria solani (accession number CPO22033.1) and 100\% homology and 72\% coverage with $A$. alternata (accession number XM_01852723.1), indicating a possible cross reaction to species commonly present in apple orchards. While, in the study by Daniëls et al. (2012), it is suggested to design new primers and a hydrolysis probe to analyze naturally infected samples because of the cross reaction with other Venturia species. Both methods needed some improvements to meet an adequate specificity.

An important factor for fungicide application in the field is the quantification of the inoculum of airborne plant pathogens. A tool to quantify the airborne inoculum is the spore trap (Ribbert et al. 2007; Sholberg et al. 2005; West and Kimber 2015), which is used to capture airborne fungal spores on adhesive tape, to be counted later under an optical microscope, to quantify the inoculum of $V$. inaequalis, and to plan phytosanitary treatments (MacHardy 1996; West and Kimber 2015). Current limitations with the use of spore traps are mainly related to the long time spent counting $V$. inaequalis ascospores under an optical microscope on the tapes and the need for a quick response to program fungicide management. Different studies have used spore traps in combination with qPCR to quantify the airborne inoculum of plant pathogens (Carisse et al. 2005; Huang et al. 2016; Klosterman et al. 2014), including V. inaequalis (Meitz-Hopkins et al. 2014). The application of qPCR on samples from spore traps could reduce the time to analyze the samples and provide faster results even on a larger number of samples.

To date, no studies used spore traps combined with TaqMan qPCR assays. The aim of the current work was to develop and validate a new specific TaqMan qPCR assay that could be used to detect and quantify $V$. inaequalis on different Malus $\times$ domestica cultivars, both in the leaves and fruit. $V$. inaequalis isolates from different fields and growing seasons were used to evaluate the assay specificity. Moreover, different plant materials (symptomatic and asymptomatic) and artificially inoculated leaves were tested. The assay was validated for specificity on 20 different species, including Venturia asperata, which has recently been reported as a pathogen on scabresistant varieties of apple having the Rvi6 gene (Caffier et al. 2012; Turan et al. 2019) and on the other species showing crossreactions in previously published qPCR assays. Furthermore, the assay was tested on spore trap samples to detect and quantify the airborne inoculum of $V$. inaequalis.

\section{Materials and Methods}

Fungal strains. Strains of $V$. inaequalis were isolated from leaves of apple tree (Malus $\times$ domestica) cultivars Ambrosia, Golden Delicious, and Mondial Gala, cultivated in northern Italy (Piedmont) during 2015 and 2016. Thirty-five isolates were selected for this study. Fungi that are pathogenic or commonly present in apple orchards were isolated from symptomatic and asymptomatic apple leaves. All the isolates were identified through the amplification of the ribosomal DNA ITS region, following the protocol by White et al. (1990). Reference strains (V. inaequalis CBS 815.69, V. asperata IRHS 2345, $V$. pirina CBS 120.825, V. nashicola CBS 794.84, V. cerasi CBS 444.54, and Fusicladium carpophilum CBS 497.62) and strains from the Agroinnova collection were used to verify the assay specificity. The strains used in this study are summarized in Table 1 and were maintained as monoconidial cultures in tubes of malt extract agar (MEA) (Sigma Aldrich, Germany) and were stored at $4{ }^{\circ} \mathrm{C}$.

Fungal DNA extraction and quantification. Strains of Venturia spp. were grown on MEA for 30 days at $20 \pm 1{ }^{\circ} \mathrm{C}$ in the dark, while the other fungal species were grown for 10 days at $25 \pm 1^{\circ} \mathrm{C}$. The fungal DNA was extracted from approximately $100 \mathrm{mg}$ of fresh-weight mycelium, using an Omega E.Z.N.A. Fungal DNA Mini Kit (VWR, Radnor, PA, USA), according to manufacturer instructions. The DNA quality and the concentration were measured using a Nanodrop 2000 Spectrophotomer (Thermo Scientific, Wilmington, DE, USA).

Sequence analysis of the translation elongation factor gene and design of primers and hydrolysis probe. The translation elongation factor 1 alpha $(E F 1-\alpha)$ sequences were amplified for the $35 \mathrm{~V}$. inaequalis strains, using ELF1 (CGAGAAGTTCGAGAAGGT) and ELF2 (CCAATGACGGTGACATAG) primers (Gladieux et al. 2010). PCR was carried out using Taq DNA polymerase kit (Qiagen, Hilden, Germany) in a total volume of $25 \mu \mathrm{l}$, containing $2.5 \mu \mathrm{l}$ of Qiagen PCR buffer $10 \times, 0.5 \mu \mathrm{l}$ of $\mathrm{MgCl}_{2}, 0.75 \mu \mathrm{l}$ of $\mathrm{dNTPs}$ $(10 \mathrm{mM}), 1 \mu \mathrm{l}$ of each primer $(10 \mu \mathrm{M}), 0.2 \mu \mathrm{l}$ of Taq DNA polymerase, and $20 \mathrm{ng}$ of template DNA. The thermal cycling program was an initial denaturing step of $95^{\circ} \mathrm{C}$ for $5 \mathrm{~min}$, followed by $95^{\circ} \mathrm{C}$ for $40 \mathrm{~s}, 58^{\circ} \mathrm{C}$ for $50 \mathrm{~s}$, and $72^{\circ} \mathrm{C}$ for $1 \mathrm{~min}$ (for 35 cycles), and a final extension at $72^{\circ} \mathrm{C}$ for $5 \mathrm{~min}$. After agarose gel electrophoresis, the PCR products were purified using a QIAquick PCR purification kit (Qiagen) and were sequenced in both directions by Macrogen, Inc. (Amsterdam, The Netherlands). The consensus sequences were obtained by assembling forward and reverse sequences, using DNA Baser (Heracle Biosoft, Romania). The consensus sequences obtained for the $V$. inaequalis strains were compared with those deposited in GenBank and a multialignment was performed, using the CLUSTALW algorithm, through Molecular Evolutionary Genetics Analysis (MEGA6) software, version 6.0 (Supplementary Fig. S1). The alignment was used to design the primers and hydrolysis probes used in this study.

Six sets of primers and two hydrolysis probes were designed using Primer Express software 3.0 (Applied Biosystems, Foster City, CA, USA) and are listed in Table 2 . The hydrolysis probes were labeled at the $5^{\prime}$ end with the 6-carboxyfluorescein dye reporter and Black Hole Quencher (BHQ1) or the nonfluorescent quencher minor groove binder (NF-MGB) at the 3 -end. OligoCalc tool (http://biotools.nubic.northwestern.edu/OligoCalc.html) was used to verify the presence of hairpins and potential secondary structures, while in silico specificity was verified using the BLASTN tool of the National Center of Biotechnology Information (https://blast.ncbi.nlm.nih. gov/Blast.cgi). Invitrogen (Carlsbad, CA, U.S.A.) and Metabion (Steinkirchen, Germany) synthesized primers and hydrolysis probes, respectively.

Conventional end-point PCR and qPCR optimization and amplification. The primer pair sets were first assessed by means of conventional end-point PCR using DNA from $V$. inaequalis strains and other selected species. The PCR end-point assays were performed using a Taq DNA polymerase kit (Qiagen) in a $25-\mu 1$ reaction, composed of $2 \mu \mathrm{l}$ of Qiagen buffer $10 \times, 0.8 \mu \mathrm{l}$ of $\mathrm{MgCl}_{2}, 1 \mu \mathrm{l}$ of dNTPs $(10 \mathrm{mM}), 1 \mu \mathrm{l}$ of each primer $(10 \mu \mathrm{M}), 0.2 \mu \mathrm{l}$ of Taq Platinum Pfx DNA polymerase (Invitrogen, Waltham, MA, USA) and $20 \mathrm{ng}$ of DNA. The PCR thermal cycler conditions were $3 \mathrm{~min}$ at $95^{\circ} \mathrm{C}$ followed by 30 cycles of $95^{\circ} \mathrm{C}$ for $45 \mathrm{~s}, 54^{\circ} \mathrm{C}$ for $45 \mathrm{~s}, 72^{\circ} \mathrm{C}$ for $1 \mathrm{~min}$, and a final extension of $5 \mathrm{~min}$. The PCR products were run on $1 \%$ agarose gel in a Tris-borate-EDTA buffer and were visualized under a UV transilluminator, using the Quantity One software (BioRad Labs, Hercules, CA, USA). After performing end-point PCR, the primer pairs that gave the best results were selected and were used in qPCR with SYBR Green in order to compare them with the specificity and sensitivity of the TaqMan qPCR assay. Real-time reactions were performed using a StepOnePlus qPCR system (Applied Biosystems), with 96 well-plates (Optical reaction plate; Applied Biosystems) sealed with MicroAmp optical adhesive film (Applied Biosystems).

SYBR Green reactions were carried out using $10 \mu$ l of Power SYBR Green Mastermix 10× (Applied Biosystems), $1 \mu$ l of each primer $(3 \mu \mathrm{M})$, and $1 \mu \mathrm{l}$ of template DNA. Amplification conditions were $95^{\circ} \mathrm{C}$ for $10 \mathrm{~min}$, followed by 40 cycles of $57^{\circ} \mathrm{C}$ for $1 \mathrm{~min}$ and $95^{\circ} \mathrm{C}$ for $15 \mathrm{~s}$. The melting curves were acquired after each run at the following conditions: $95^{\circ} \mathrm{C}$ for $15 \mathrm{~s}, 60^{\circ} \mathrm{C}$ for $15 \mathrm{~s}$, and $95^{\circ} \mathrm{C}$ for $15 \mathrm{~s}$. Sterile water was used as a negative control. To determine the sensitivity of the SYBR Green assay, a standard curve was obtained with $V$. inaequalis DNA using strain $1 \mathrm{~b} 14$ eightfold serially diluted (from $20 \mathrm{ng}$ to $2 \mathrm{fg}$ ).

The TaqMan qPCR assay was performed using TaqMan Universal Mastermix 2x (Applied Biosystems). Each 96-well plate was loaded with a negative control, standard DNA, and a positive control in triplicate. Different primer concentrations (from 3 to $0.3 \mu \mathrm{M}$ ) and 
different temperatures were initially tested at the annealing stage (57 to $60^{\circ} \mathrm{C}$ ). Reactions were carried out in a final volume of $20 \mu \mathrm{l}$, with $1 \mu \mathrm{l}$ of DNA ( $\cong 20 \mathrm{ng}), 0.4 \mu \mathrm{l}$ of each primer $(3 \mu \mathrm{M})$, and $0.2 \mu \mathrm{l}$ of hydrolysis probe $(5 \mu \mathrm{M})$. Sterile water was used as a negative control. Amplification conditions were $95^{\circ} \mathrm{C}$ for $10 \mathrm{~min}, 40$ cycles of $57^{\circ} \mathrm{C}$ for $1 \mathrm{~min}$, and $95^{\circ} \mathrm{C}$ for $15 \mathrm{~s}$. The newly developed TaqMan qPCR assay was compared, in terms of sensitivity and specificity, with the TaqMan qPCR assay previously published by Gusberti et al. (2012).

The quantification cycle (Cq) values (Bustin et al. 2009) generated by qPCR were compared with the standard curve to quantify the
DNA of $V$. inaequalis in target samples. The approximate number of cells was calculated by dividing the DNA quantity by the weight of the genome of $V$. inaequalis (0.0000597 ng) (Deng et al. 2017), thereby obtaining the number of target cells ( $V$. inaequalis) per microliter of reaction, using TaqMan Universal Mastermix $2 \times$ (Applied Biosystems).

Specificity, sensitivity, selectivity, repeatability, and reproducibility of the TaqMan qPCR assay. The TaqMan qPCR assay was validated according to the international EPPO standard PM 7/98 (EPPO 2014). In order to evaluate the specificity of the assay for $V$. inaequalis, 20 different species, including other pathogenic

Table 1. Strain ID, host, source of isolation, and origin of the fungal species used in this study to develop the TaqMan quantitative PCR assay

\begin{tabular}{|c|c|c|c|c|}
\hline Species & Strain ID & Host & Source & Origin \\
\hline Venturia inaequalis & $1 \mathrm{~b} 1$ & Malus $\times$ domestica 'Ambrosia' & Leaf & Italy \\
\hline$V$. inaequalis & $1 \mathrm{~b} 5$ & Malus $\times$ domestica 'Ambrosia' & Leaf & Italy \\
\hline V. inaequalis & $1 \mathrm{~b} 10$ & Malus $\times$ domestica 'Ambrosia' & Leaf & Italy \\
\hline V. inaequalis & $1 \mathrm{~b} 7$ & Malus $\times$ domestica 'Ambrosia' & Leaf & Italy \\
\hline$V$. inaequalis & $1 \mathrm{~b} 6$ & Malus $\times$ domestica 'Ambrosia' & Leaf & Italy \\
\hline$V$. inaequalis & 116_c2 & Malus $\times$ domestica 'Ambrosia' & Leaf & Italy \\
\hline V. inaequalis & 216_b4 & Malus $\times$ domestica 'Golden Delicious' & Leaf & Italy \\
\hline V. inaequalis & $3 b 6$ & Malus $\times$ domestica 'Ambrosia' & Leaf & Italy \\
\hline V. inaequalis & $3 \mathrm{~b} 2$ & Malus $\times$ domestica 'Ambrosia' & Leaf & Italy \\
\hline V. inaequalis & $3 \mathrm{~b} 5$ & Malus $\times$ domestica 'Ambrosia' & Leaf & Italy \\
\hline V. inaequalis & 516_6 & Malus $\times$ domestica 'Ambrosia' & Leaf & Italy \\
\hline V. inaequalis & 516_2 & Malus $\times$ domestica 'Ambrosia' & Leaf & Italy \\
\hline V. inaequalis & 516_3 & Malus $\times$ domestica 'Ambrosia' & Leaf & Italy \\
\hline$V$. inaequalis & $3 \mathrm{aa}$ & Malus $\times$ domestica 'Golden Delicious' & Leaf & Italy \\
\hline V. inaequalis & $3 a 1$ & Malus $\times$ domestica 'Golden Delicious' & Leaf & Italy \\
\hline V. inaequalis & $3 a c$ & Malus $\times$ domestica 'Golden Delicious' & Leaf & Italy \\
\hline$V$. inaequalis & 416_a12 & Malus $\times$ domestica 'Mondial Gala' & Leaf & Italy \\
\hline$V$. inaequalis & 416_a5 & Malus $\times$ domestica 'Mondial Gala' & Leaf & Italy \\
\hline V. inaequalis & 416_a9 & Malus $\times$ domestica 'Mondial Gala' & Leaf & Italy \\
\hline$V$. inaequalis & 516_h & Malus $\times$ domestica 'Ambrosia' & Leaf & Italy \\
\hline V. inaequalis & $516 \_4$ & Malus $\times$ domestica 'Ambrosia' & Leaf & Italy \\
\hline V. inaequalis & 516_5 & Malus $\times$ domestica 'Ambrosia' & Leaf & Italy \\
\hline V. inaequalis & $3 \mathrm{af}$ & Malus $\times$ domestica 'Golden Delicious' & Leaf & Italy \\
\hline$V$. inaequalis & 416_b2 & Malus $\times$ domestica 'Golden Delicious' & Leaf & Italy \\
\hline V. inaequalis & 416_a1 & Malus $\times$ domestica 'Mondial Gala' & Leaf & Italy \\
\hline V. inaequalis & 516_10 & Malus $\times$ domestica 'Ambrosia' & Leaf & Italy \\
\hline V. inaequalis & $1 \mathrm{~b} 2$ & Malus $\times$ domestica 'Ambrosia' & Leaf & Italy \\
\hline V. inaequalis & 416_a13 & Malus $\times$ domestica 'Mondial Gala' & Leaf & Italy \\
\hline V. inaequalis & $1 b 9$ & Malus $\times$ domestica 'Ambrosia' & Leaf & Italy \\
\hline V. inaequalis & $3 b 3$ & Malus $\times$ domestica 'Ambrosia' & Leaf & Italy \\
\hline V. inaequalis & $3 b 4$ & Malus $\times$ domestica 'Ambrosia' & Leaf & Italy \\
\hline V. inaequalis & $3 \mathrm{~b} 10$ & Malus $\times$ domestica 'Ambrosia' & Leaf & Italy \\
\hline$V$. inaequalis & $1 \mathrm{~b} 14$ & Malus $\times$ domestica 'Ambrosia' & Leaf & Italy \\
\hline$V$. inaequalis & 416_a3 & Malus $\times$ domestica 'Mondial Gala' & Leaf & Italy \\
\hline V. inaequalis & $1 b 13$ & Malus $\times$ domestica 'Ambrosia' & Leaf & Italy \\
\hline$V$. inaequalis & CBS 815.69 & Malus sylvestris & Fruit & The Netherlands \\
\hline V. cerasi & CBS 444.54 & Prunus cerasus & Unknown & Germany \\
\hline$V \cdot$ pirina & CBS 120.825 & Pyrus communis & Unknown & Brazil \\
\hline V. nashicola & CBS 794.84 & Pyrus serotina var. Culta & Unknown & Japan \\
\hline V. asperata & IRHS 2345 & Malus $\times$ domestica & Fruit & France \\
\hline Monilia fructicola & MON1 & Malus $\times$ domestica & Leaf & Italy \\
\hline Monilia laxa & LAXA3 & Prunus persica & Fruit & Italy \\
\hline Botryosphaeria dothidea & BOTRYO1 & Malus $\times$ domestica & Leaf & Italy \\
\hline Sclerotinia sclerotiorum & SCLA2 & Unknown & Unknown & Italy \\
\hline Colletotrichum fioriniae & COLLRIV & Malus $\times$ domestica & Fruit & Italy \\
\hline Epicoccum nigrum & EPI2 & Malus $\times$ domestica & Leaf & Italy \\
\hline Stemphylium sp. & STEM & Pyrus communis & Fruit & Italy \\
\hline Cladosporium cladosporioides & CLAD1 & Malus $\times$ domestica & Leaf & Italy \\
\hline Alternaria mali & CBS 106.24 & Malus sylvestris & Unknown & U.S.A. \\
\hline Alternaria $\mathrm{sp}$. & MALT1 & Malus $\times$ domestica & Leaf & Italy \\
\hline Botrytis cinerea & BOT1 & Malus $\times$ domestica & Leaf & Italy \\
\hline Phoma sp. & PH5 & Malus $\times$ domestica & Leaf & Italy \\
\hline Fusarium equiseti & 3FEQS & Unknown & Unknown & Italy \\
\hline Penicillium expansum & PEX16 & Malus $\times$ domestica & Leaf & Italy \\
\hline Ramularia mali & RM2 & Malus $\times$ domestica & Fruit & Italy \\
\hline
\end{tabular}


Venturia species that affect different hosts and $V$. asperata, which has recently been reported in Italy on apples, were used (Table 1). The presence of aspecific amplification signals was evaluated after 40 cycles in different experiments.

To determine the sensitivity of the TaqMan qPCR assay, a standard calibration curve was obtained with $V$. inaequalis DNA using the $1 \mathrm{~b} 14$ strain eightfold serially diluted (from $20 \mathrm{ng}$ to $2 \mathrm{fg}$ ) in sterile deionized water. Furthermore, to verify the influence of the host DNA on $V$. inaequalis amplification, the pathogen DNA was eightfold diluted in Malus $\times$ domestica cultivars Ambrosia, Mondial Gala, and Golden Delicious DNA (host DNA concentration of $10 \mathrm{ng} / \mu \mathrm{l}$ ). The standard curve reaction was carried out in triplicate and was used as an internal control in order to quantify the target DNA in different samples. Repeatability was checked by running three independent assays of the test. Two different operators tested the reproducibility of the assay in two different laboratories and on different days.

Detection of $V$. inaequalis in naturally infected Malus $\times$ domestica leaves and in apple fruit. During the 2015 through 2017 seasons, leaves from Malus $\times$ domesica plants showing symptoms of apple scab were harvested and stored for DNA extraction. A total of 29 samples were collected (11 from Ambrosia, 11 from Golden Delicious, and seven from Mondial Gala leaves). Furthermore, four Golden Delicious apples that had been stored for 2 months and which showed apple scab symptoms were selected for DNA extraction. DNA from the infected leaves and fruits were extracted from approximately $100 \mathrm{mg}$ fresh weight of leaves or fruit. The samples were previously freeze-dried, were round with liquid nitrogen, and were then extracted with E.Z.N.A. Plant DNA kit (VWR), following manufacturer instructions.

Detection of $V$. inaequalis in asymptomatic Malus $\times$ domestica leaves. A total of 30 samples of asymptomatic Ambrosia, Florina, and Golden Delicious leaves were analyzed in May of 2018 to assess the presence of $V$. inaequalis, using the TaqMan qPCR assay. The leaves were divided into two equal parts, using sterile blades, to obtain the $100 \mathrm{mg}$ needed for the DNA extraction. The DNA extraction was performed as previously described.

Detection of $V$. inaequalis in artificially inoculated Malus $\times$ domestica leaves. $V$. inaequalis conidia were obtained from a single spore strain (1b14), according to Parker et al. (1995). Leaves were obtained from Malus $\times$ domestica 'Florina' plants. The absence of $V$. inaequalis in the plant material was confirmed using a binocular microscope (Nikon Eclipse 55i; Tokyo). Leaf disks (1 cm diameter) were collected for the assay, were disinfected with a $10 \%$ solution of sodium hypochlorite, were washed by immersion in sterile deionized water, and were air-dried. The inoculation of the leaf disks was performed on the adaxial leaf surface with an initial concentration of $10^{2}$ conidia per milliliter of $V$. inaequalis (three drops of $5 \mu \mathrm{l}$ each), which was subsequently serially diluted $(1: 2,1: 3,1: 5,1: 10,1: 15$, $1: 20,1: 50$, and 1:100). Control leaves were prepared in a similar way with sterile deionized water. Two replicates were tested for each conidial concentration. DNA was extracted from artificially inoculated leaves $60 \mathrm{~min}$ after inoculation, following the procedures previously described in the paragraph about detection of $V$. inaequalis in naturally infected Malus $\times$ domestica leaves and apple fruits.

Detection of $\boldsymbol{V}$. inaequalis from spore trap samples. A volumetric spore sampler (Burkard Manufacturing Co. Ltd., Rickmansworth, Hertfordshire, UK), placed in an apple orchard in Manta (Cuneo, Italy), was used to detect the airborne conidia of $V$. inaequalis. The tapes were collected at 24-h intervals for 14 days (from May 1 to May 14, 2018). Each daily tape was first visualized under an optical microscope to count the $V$. inaequalis cells at $40 \times$ magnification. The same segments were subsequently placed in 50-ml tubes and were stored at $4{ }^{\circ} \mathrm{C}$ until processing. An aliquot of $25 \mathrm{ml}$ of a polyethylene glycol (PEG) alkaline buffer (50 g of PEG average $M_{n} 4600$ per liter, $20 \mathrm{mM} \mathrm{KOH}, \mathrm{pH} 13.5$ ) was added to each tube and was vortexed for $20 \mathrm{~min}$ for the DNA extraction. After incubating for $1 \mathrm{~h}$ at $65^{\circ} \mathrm{C}$, the samples were vortexed for $20 \mathrm{~min}$ and were centrifuged for $30 \mathrm{~min}$ at $8,000 \times g$. The supernatant was collected and the DNA was extracted using an E.Z.N.A. Fungal DNA Mini kit, according to manufacturer protocol, by adjusting the buffer volumes. Repeatability of the assay on spore trap samples was evaluated by performing six independent reactions using the same set of samples.

Data analysis. StepOne software was used to automatically generate the baseline range and the qPCR standard curves, as well as to determine the $\mathrm{Cq}$ values. Student's $t$ test was used to analyze the reproducibility of the assay.

\section{Results}

TaqMan qPCR assay optimization. The $E F 1-\alpha$ gene was selected because of the presence of a conserved region and the deletion of 31 nucleotides in the $V$. inaequalis species, enabling differentiation from the other Venturia species, including $V$. asperata. The alignment of partial $E F 1-\alpha$ gene sequences from different $V$. inaequalis strains and five other Venturia species was used to design the primers and hydrolysis probes reported in Table 2 . The F1/R11 primer pair, which gave the best results with conventional endpoint PCR, by amplifying only $V$. inaequalis strains without any nonspecific bands on agarose gel electrophoresis, was selected for the real-time assays. The optimization of the TaqMan qPCR assays was tested using different primer and hydrolysis probe concentrations and considering different cycling conditions. The best conditions were found with a primer concentration of $3 \mu \mathrm{M}$ and an annealing temperature of $57^{\circ} \mathrm{C}$ for $1 \mathrm{~min}$. The Ven 1 hydrolysis probe and F1/R11 primer pair were selected for the TaqMan qPCR assay, as

Table 2. Primer pairs and hydrolysis probes, designed on the EF1- $\alpha$ gene used for the detection of Venturia inaequalis with the TaqMan quantitative PCR assay

\begin{tabular}{|c|c|c|}
\hline Primers and hydrolysis probes & Amplicon (bp) & Sequence $\left(5^{\prime}-3^{\prime}\right)$ \\
\hline F 3.2/R11 & $191 \mathrm{bp}$ & $\begin{array}{l}\text { ACCCGGATTTCATTTCGAAACT } \\
\text { GCAATCGTTAGCATCGTCATAGTG }\end{array}$ \\
\hline F $4.4 / R 11$ & $154 \mathrm{bp}$ & $\begin{array}{c}\text { TTTTGCACTGTGGCAGCCC } \\
\text { GCAATCGTTAGCATCGTCATAGTG }\end{array}$ \\
\hline $\mathrm{F} 1 / \mathrm{R} 11$ & 86 bp & $\begin{array}{c}\text { CACTTCCCCGCTATTCACGT } \\
\text { GCAATCGTTAGCATCGTCATAGTG }\end{array}$ \\
\hline F 2.3/R6 & $127 \mathrm{bp}$ & $\begin{array}{l}\text { TTGCCCCTCCAAAATTACAGTG } \\
\text { GGCGGCTTCCTATTGCAATC }\end{array}$ \\
\hline F1/R6 & $100 \mathrm{bp}$ & CACTTCCCCGCTATTCACGT GGCGGCTTCCTATTGCAATC \\
\hline F 4.3/R6 & $171 \mathrm{bp}$ & AAATTTTGCACTGTGGCAGC GGCGGCTTCCTATTGCAATC \\
\hline F $2.2 / \mathrm{R} 6$ & $127 \mathrm{bp}$ & $\begin{array}{l}\text { TTGCCCCTCCAAAATTACAGT } \\
\text { GGCGGCTTCCTATTGCAATC }\end{array}$ \\
\hline Vina & - & $\begin{array}{c}{[\text { FAM] }- \text { AGCCCAACTT }} \\
\text { TCTCCGGTCC-[NF-MGB] }\end{array}$ \\
\hline Ven1 & _ & [FAM]-CTCAAGGCAGCCCAACTTTCTCCGGT-[BHQ1] \\
\hline
\end{tabular}


they showed the most suitable amplification, using TaqMan Universal Mastermix 2x (Applied Biosystems).

Specificity, sensitivity, selectivity, repeatability, and reproducibility of the TaqMan qPCR assay. The TaqMan qPCR assay, with the selected primer pair and hydrolysis probe, was able to amplify the 86-bp fragment of the EF1- $\alpha$ gene in different experiments from 35 $V$. inaequalis strains (Supplementary Table S1). No amplification was detected after 40 cycles for V. asperata, V. pirina, V. carpophila,

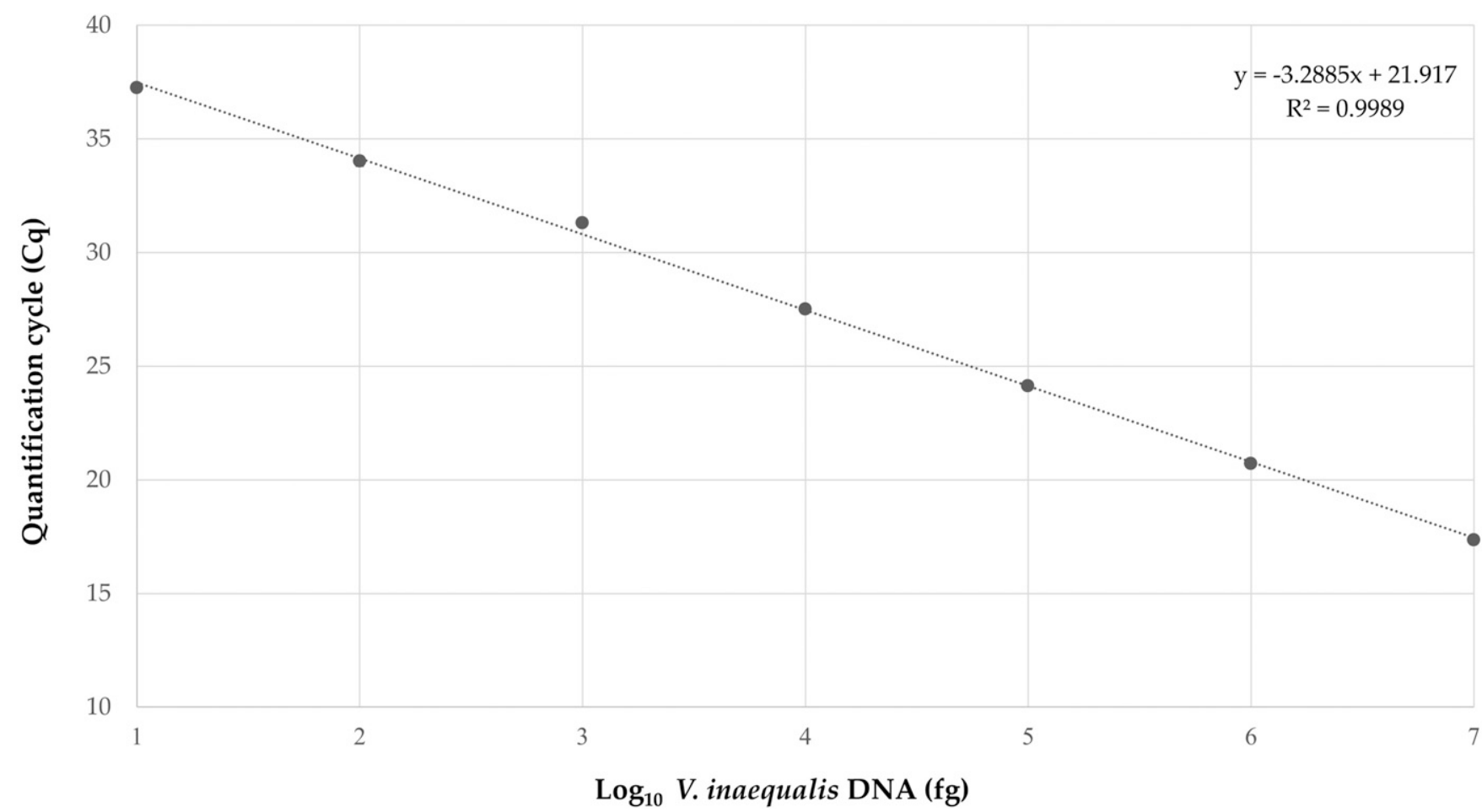

Fig. 1. Standard curve obtained with genomic DNA of the Venturia inaequalis $1 \mathrm{~b} 14$ strain showing the correlation between the $V$. inaequalis DNA amount (from $20 \mathrm{ng}$ to $20 \mathrm{fg}$ ) and the quantification cycle values (the standard deviation values range from 0.04 to 0.22 , thus the standard deviation bars are too small to display on the graph). The dilutions were run in triplicate.

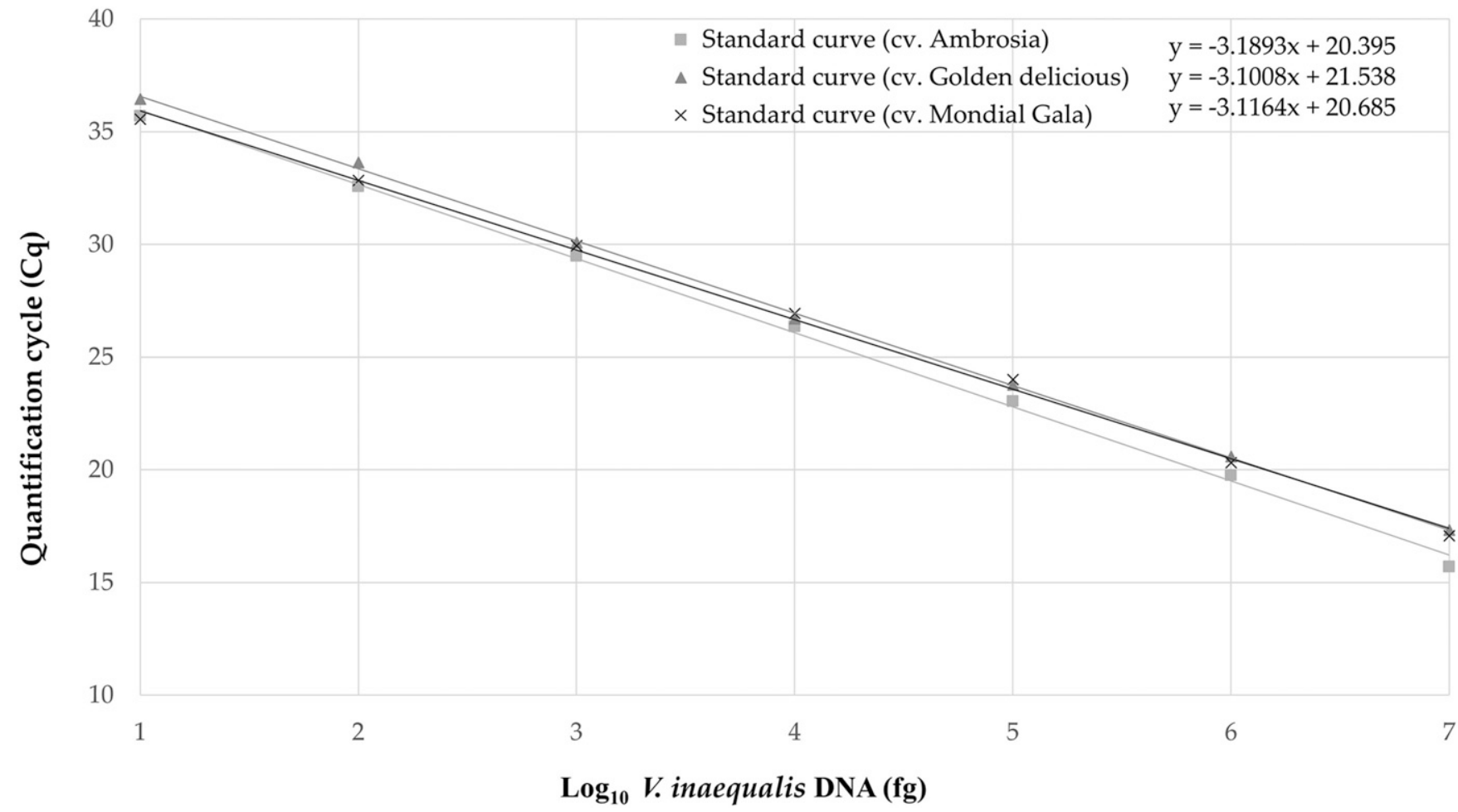

Fig. 2. Standard curve obtained with genomic DNA of the Venturia inaequalis $1 \mathrm{~b} 14$ strain diluted in $10 \mathrm{ng}$ of DNA from Malus $\times$ domestica 'Ambrosia', 'Golden Delicious', and 'Mondial Gala'. The amount of $V$. inaequalis DNA is plotted against quantification cycle values (the standard deviation values range from 0.03 to 0.53 , thus the standard deviation bars are too small to display on the graph). The dilutions were run in triplicate. 
V. cerasi, V. naschicola, or for the other tested species listed in Table 1.

The DNA of $V$. inaequalis, serially diluted from $20 \mathrm{ng}$ to $0.2 \mathrm{fg}$ in sterile distilled water, was used to build a standard curve to evaluate the limit of detection (LOD). The pathogen was quantifiable from $20 \mathrm{ng}$ to $20 \mathrm{fg}$ (Fig. 1), and a LOD Cq, ranging between 36 and 37 , was obtained. The LOD of $20 \mathrm{fg}$ is lower than a single genome of $V$. inaequalis (0.0000597 ng [Deng et al. 2017]). The mean value of the regression slope was -3.28 , and the mean relative efficiency was between 99 and $110 \%$. No influence was observed on the selectivity of the TaqMan qPCR assay when $V$. inaequalis DNA serially diluted in Ambrosia, Golden Delicious, and Mondial Gala DNA was used (Fig. 2). The amplifications showed similar PCR efficiencies and a reliable correlation between the $\mathrm{Cq}$ values and the amount of measured $V$. inaequalis DNA (Fig. 2), showing, also, the lack of nonspecific amplification of the DNA of three cultivars of apple. No statistical differences $(P>0.05)$ were found for the results of the student's $t$ test, which was used to analyze the repeatability and reproducibility of the assay.

Specificity and sensitivity comparison of the SYBR Green and TaqMan qPCR assays. The SYBR Green assay using the selected F1/R11 primer pair provided positive results for the target DNA from different cultivars, and no amplification was observed with other Venturia species after 40 cycles. However, aspecific signals were detected for some species used as negative controls, i.e., Cladosporium cladosporioides, Colletotrichum fioriniae, Fusarium equiseti, Penicillium expansum, and Phoma sp., after 34 to 36 cycles. These species often showed double peaks in the melt analysis, with one peak at $79.17^{\circ} \mathrm{C}$, similar to $V$. inaequalis positive control, and one peak with lower melting temperature $\left(67.87^{\circ} \mathrm{C}\right)$. The sensitivity of the assay with SYBR Green revealed a 10-fold higher LOD (200 fg) than the TaqMan qPCR assay designed on the EF1- $\alpha$ gene.

The TaqMan qPCR assay previously developed by Gusberti et al. (2012) gave a cross-reaction for the strain MALT1 (identified as Alternaria arborescens species complex, based on the ITS, OPA 10-2, and endopolygacturonase sequences) isolated from apple leaves ( $\mathrm{Cq}$ after 35 to 36 cycles), while no amplification was obtained with other tested species. Sensitivity, assessed using the method by Gusberti et al. (2012) on the $V$. inaequalis $1 \mathrm{~b} 14$ strain, showed a LOD of $100 \mathrm{fg}$ (Supplementary Table S2; Supplementary Fig. S2).

Detection of $V$. inaequalis in naturally infected Malus $\times$ domestica leaves and fruit. The TaqMan qPCR assay was used to quantify $V$. inaequalis in naturally infected leaves of three Malus $\times$ domestica cultivars and apple fruit. No influence of the host DNA was detected, and all the analyzed samples resulted positive for the target amplification (Fig. 3A; Supplementary Table S3). The average number of cells per microliter was $5.26 \times 10^{4}$ for the Ambrosia

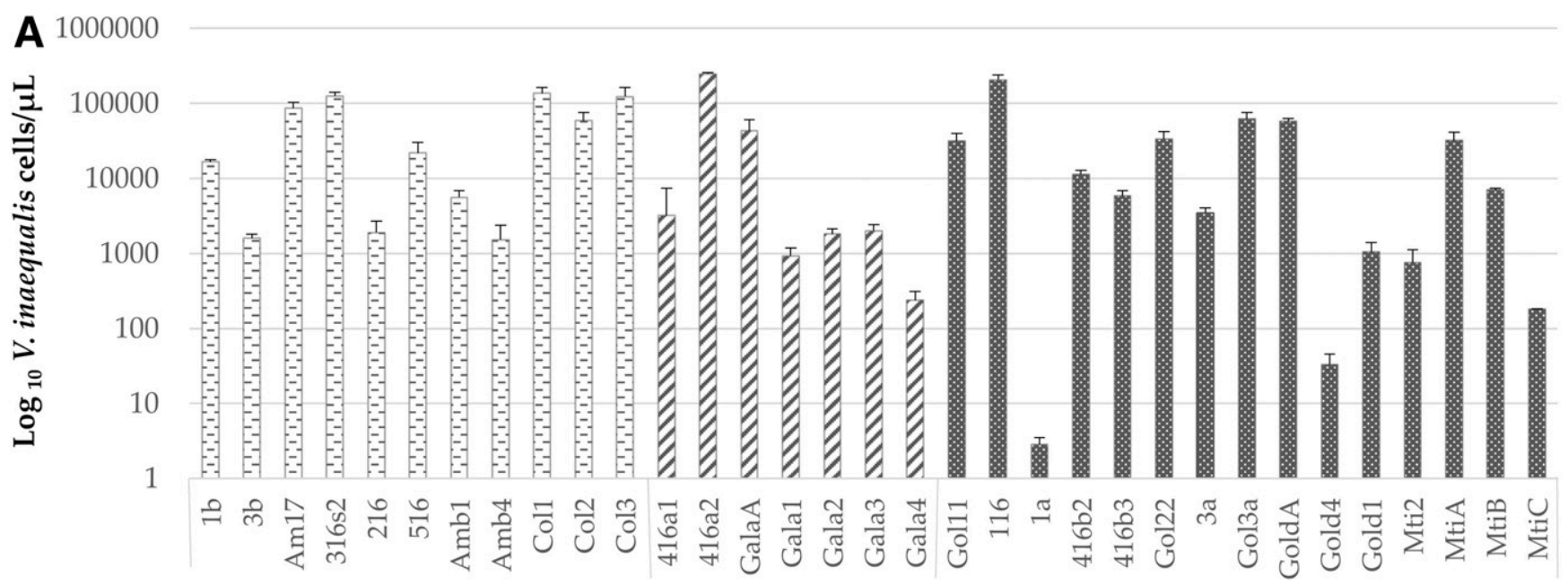

[- Malus $x$ domestica 'Ambrosia' $\square$ Malus $x$ domestica 'Mondial Gala' Malus $x$ domestica 'Golden Delicious'

B

Malus $x$ domestica 'Florina'

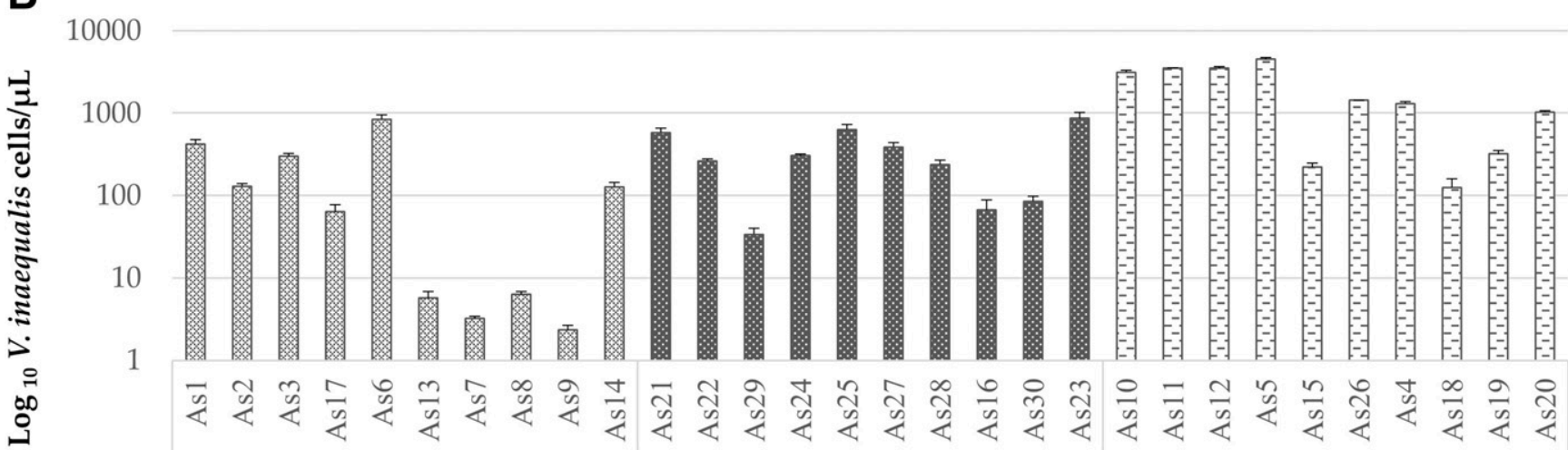

\section{Sample ID}

Fig. 3. Detection of Venturia inaequalis with the TaqMan quantitative PCR assay on A, naturally infected leaves of Malus $\times$ domestica 'Ambrosia', 'Golden Delicious', and 'Mondial Gala' and Golden Delicious fruits, and B, asymptomatic leaves of Malus $\times$ domestica 'Ambrosia', 'Golden Delicious', and 'Florina'. The values are expressed as the mean \pm standard deviation $(n=9)$. The sample ID represents leaves derived from different trees. 
samples, $4.28 \times 10^{4}$ for the Mondial Gala samples, and $3.76 \times 10^{4}$ for the Golden Delicious samples. The assay was able to detect $2.83 \mathrm{~V}$. inaequalis cells per microliter in the naturally infected leaves (mean $\mathrm{Cq} 34.35$ ) and 182 cells per microliter in the naturally infected fruit (mean Cq 28.38) (Fig. 3A; Supplementary Table S3).

Detection of $V$. inaequalis in asymptomatic Malus $\times$ domestica leaves. The TaqMan qPCR assay was able to detect $V$. inaequalis in both the asymptomatic resistant cultivar Florina and susceptible cultivars Ambrosia and Golden Delicious (Fig. 3B; Supplementary Table S4). The lowest concentration of $0.02 \times 10^{2}$ cells per microliter was found in the As9 sample (resistant Florina), while the highest concentration of $4.50 \times 10^{3}$ cells per microliter was found in the susceptible Ambrosia'sample (As5). The mean V. inaequalis concentration with Florina, Golden Delicious, and Ambrosia samples was $1.90 \times 10^{2}, 3.46 \times 10^{2}$, and $1.91 \times 10^{3}$ cells per microliter, respectively.
Detection of $V$. inaequalis in artificially inoculated Malus $\times$ domestica leaves. The developed TaqMan qPCR assay was further tested on Malus $\times$ domestica leaves artificially inoculated with a $V$. inaequalis conidial suspension. The results obtained for the quantification of $V$. inaequalis are reported in Figure 4. All the samples amplified with a clear amplification signal, with Cq ranging from 28 to 36 for samples inoculated with the highest and lowest conidial concentrations, respectively. No amplification was obtained for the negative controls. The amplification showed linearity in the serial dilutions, and the assay allowed us to quantify from $1.65 \times 10^{2}$ cells per microliter, for the initial sample, to 1.21 cells per microliter, for the 100 -fold diluted sample.

Detection of $\boldsymbol{V}$. inaequalis from spore trap samples. The TaqMan qPCR assay was used to detect and quantify the presence of airborne inoculum of $V$. inaequalis in spore trap samples. The estimated conidial concentrations, based on microscope counts, were higher

\section{0}

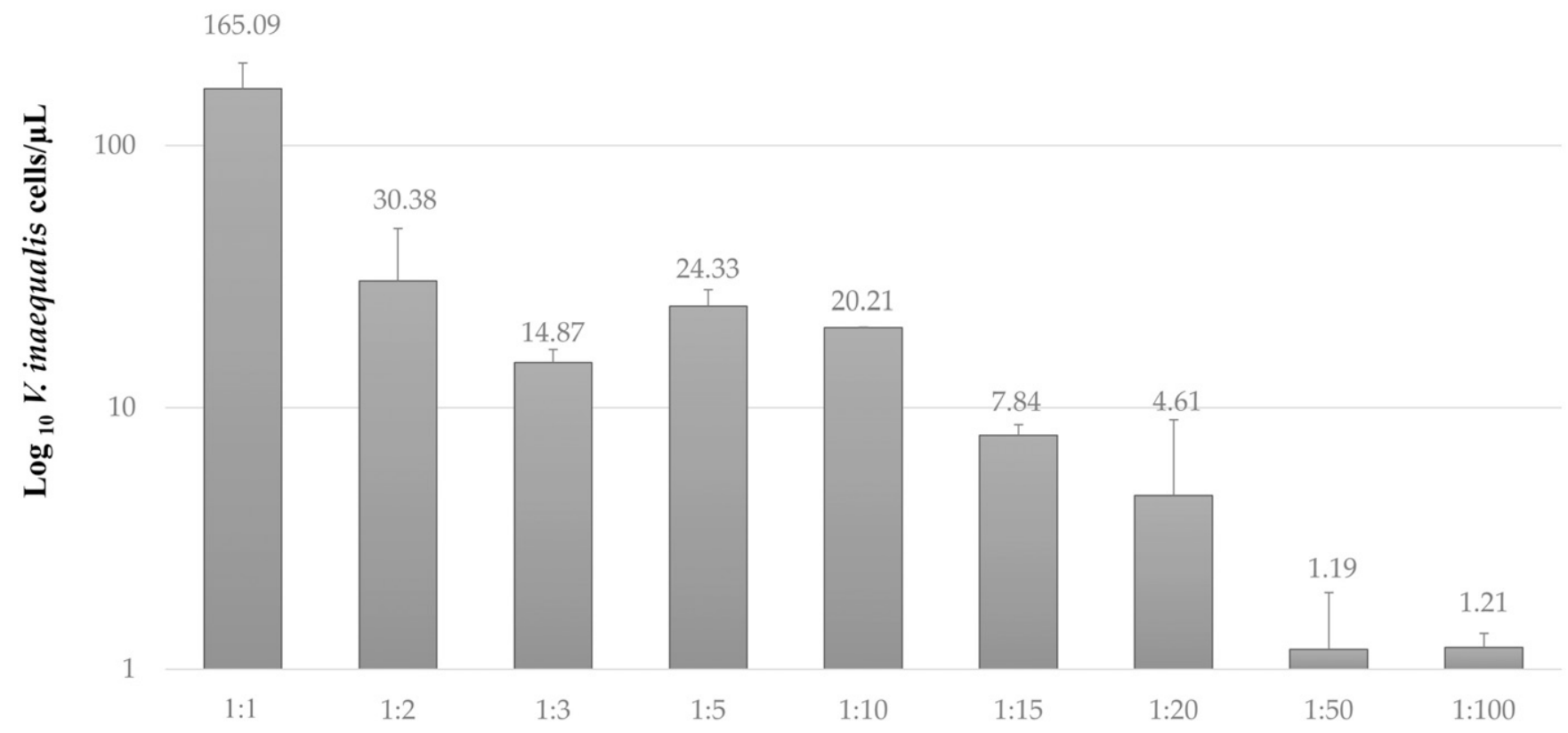

Fig. 4. Detection of Venturia inaequalis with the TaqMan quantitative PCR assay on Malus $\times$ domestica 'Ambrosia' leaf disks artificially inoculated at different concentrations. The values are expressed as the mean \pm standard deviation $(n=9)$.

Table 3. Number of Venturia inaequalis cells estimated using the optical microscope compared with the number of cells estimated with the TaqMan qPCR assay for the analyses of spore trap samples, and repeatability of the assay, expressed as the number of positive amplifications in six different reactions

\begin{tabular}{|c|c|c|c|}
\hline Sample & $\begin{array}{c}\text { Estimated number of cells } \\
\text { (optical microscope) }\end{array}$ & $\begin{array}{l}\text { Estimated number of cells } \\
\text { (TaqMan qPCR assay) }\end{array}$ & Number of positive results \\
\hline ST1 & $2.73 \times 10^{4}$ & $5.49 \times 10^{3}$ & $6 / 6$ \\
\hline ST2 & $5.21 \times 10^{4}$ & $6.88 \times 10^{3}$ & $6 / 6$ \\
\hline ST3 & $1.31 \times 10^{4}$ & $1.12 \times 10^{4}$ & $5 / 6$ \\
\hline ST4 & $7.94 \times 10^{3}$ & $4.42 \times 10^{3}$ & $6 / 6$ \\
\hline ST9 & $1.30 \times 10^{3}$ & $2.72 \times 10^{3}$ & $3 / 6$ \\
\hline ST10 & $2.05 \times 10^{3}$ & $4.80 \times 10^{3}$ & $3 / 6$ \\
\hline $\mathrm{ST} 10 / 2^{\mathrm{a}}$ & $4.67 \times 10^{2}$ & - & - \\
\hline ST11 & $8.92 \times 10^{2}$ & $1.66 \times 10^{3}$ & $2 / 6$ \\
\hline ST12 & $8.51 \times 10^{3}$ & $9.34 \times 10^{3}$ & $1 / 6$ \\
\hline ST13 & $1.37 \times 10^{3}$ & $2.58 \times 10^{3}$ & $4 / 6$ \\
\hline ST17 & $2.83 \times 10^{3}$ & $5.14 \times 10^{3}$ & $2 / 6$ \\
\hline ST21 & $1.09 \times 10^{4}$ & $7.93 \times 10^{3}$ & $2 / 6$ \\
\hline ST27 & $1.36 \times 10^{3}$ & $3.70 \times 10^{3}$ & $2 / 6$ \\
\hline ST28 & $2.21 \times 10^{3}$ & $2.52 \times 10^{3}$ & $2 / 6$ \\
\hline
\end{tabular}

${ }^{a}$ Extraction failed for the ST10/2 sample. 
than the estimated concentrations calculated from the amount of $V$. inaequalis DNA detected by the TaqMan qPCR assay. Only one of the 14 analyzed samples showed no amplification (Table 3). The estimated mean number of cells per microliter obtained from the microscope count was $1.01 \times 10^{4}$, while it was $5.26 \times 10^{3}$ for the TaqMan qPCR assay. The correlation coefficient between the two assays was positive, with an $\mathrm{R}^{2}$ value of 0.8186 . The repeatability of the assay was variable, with at least one positive amplification per sample over six reactions (Table 3 ).

\section{Discussion}

The molecular techniques currently applied for the detection of plant pathogens are often used to specifically identify and quantify fungal species in crops and food commodities (Aslam et al. 2017; Capote et al. 2012; Postollec et al. 2011). In this study, a highly sensitive TaqMan qPCR assay has been developed for the specific detection and quantification of $V$. inaequalis, and it has successfully been used with symptomatic and asymptomatic leaves, fruit, and spore trap samples.

End-point PCR permits specific detection of Venturia species (Koh et al. 2013; Schnabel et al. 1999) without sample quantification (Suarez et al. 2005), while qPCR assays are more specific, sensitive, and allow pathogen quantification (Baskarathevan et al. 2016; Kuzdraliński et al. 2017; Mirmajlessi et al. 2015; Selma et al. 2008). Real-time PCR was used in previous studies to detect and quantify $V$. inaequalis in different types of samples, using both SYBR Green I and the TaqMan chemistries.

In preliminary studies, different target sequences were explored for the development of the TaqMan qPCR assay, following multiple sequence alignments (data not shown). The sequences were obtained from strains isolated in Italy and from sequences available in the GenBank public database. Due to the high intraspecific variability, the ITS region and the beta-tubulin gene were discarded (data not shown), whereas the EFI- $\alpha$ gene proved a highly conserved species-specific region for $V$. inaequails, and it was, therefore, selected to design primers and hydrolysis probes.

SYBR Green I technology, with the same primers used to develop our TaqMan qPCR assay, and the TaqMan qPCR assay previously published by Gusberti et al. (2012) were used to compare the developed assay. By using SYBR Green I, there was a lack of specificity of the designed primers with various tested species, as described by Martínez et al. (2011). Cross-reaction was also observed in the work by Meitz-Hopkins et al. (2014), where two qPCR assays were developed, based on the CYP51A1 gene and the ITS region, amplifying $A$. alternata, which was used as negative control, while, in the study by Daniëls et al. (2012), using a qPCR assay based on the ITS region, cross-reactions with different species ( $V$. asperata, $V$. nashicola, $V$. pirina, $V$, cerasi and $V$. carpophila) are shown. With the use of SYBR Green, the sensitivity was $200 \mathrm{fg}$, five times lower than the detection limit obtained by Meitz-Hopkins et al. (2014) but two times higher than the sensitivity reported by Daniëls et al. (2012).

When the specificity was tested using hydrolysis probe technology, no cross-reaction was detected with other Venturia species, including $V$. asperata, or for other pathogens. On the contrary, when the specificity was tested with the hydrolysis probe developed by Gusberti et al. (2012), a positive amplification was obtained for Alternaria arborescens species complex from apple leaves, confirming the preliminary result of the blast search for the primers (100\% homology with $A$. solani and $A$. alternata).

Because of the high intraspecific variability that exists within the species V. inaequalis (Ebrahimi et al. 2016; Tenzer and Gessler 1999; Tenzer et al. 1999), the specificity of the assay was confirmed on DNA extracted from a large number of pure cultures of $V$. inaequalis strains, isolated from different cultivars over different years, and positive amplifications were observed for all the strains. The assay showed a low variation in the $\mathrm{Cq}$ values obtained in independent experiments and results were highly reproducible.

The Taqman qPCR assay developed in this study was more sensitive than the SYBR Green assay. The advantage of using the TaqMan qPCR assay has been reported in a qPCR comparative study by SoltanyRezaee-Rad et al. (2015). A qPCR with SYBR Green could inhibit the Taq DNA polymerase, thereby reducing the sensitivity of the assay (Kermekchiev et al. 2009). The LOD of our TaqMan qPCR assay (20 fg) proved to be more sensitive than that reported by Gusberti et al. (2012), for which the LOD was $100 \mathrm{fg}$. The LOD of the TaqMan qPCR assay (20 fg) is similar to those reported for other species, i.e., Botrytis cinerea (Suarez et al. 2005), Fusarium solani (Bernal-Martínez et al. 2012), Aspergillus fumigatus (Fernandez-Molina et al. 2014), Lichtheimia corymbifera (Springer et al. 2016), Fusarium fujikuroi (Amaral Carneiro et al. 2017), and Fusarium culmorum (Bilska et al. 2018).

The TaqMan qPCR assay was also tested to quantify the target DNA in the presence of the plant material. The sensitivity was not affected by the presence of the DNA of Malus $\times$ domestica from different cultivars, and the assay allowed us to detect and quantify $V$. inaequalis in inoculated samples with significant linearity. In our study, positive amplifications were obtained from asymptomatic leaves collected from susceptible cultivars, though $V$. inaequalis was detected in the resistant Florina cultivar at a lower concentration. The pathogen occurrence on the leaf surface of both susceptible and resistant cultivars has been reported by Bus et al. (2011) and Sarkate et al. (2018). In addition, the assay proved to be useful for the detection of the pathogen in fruit samples showing scab symptoms.

When the assay was performed on DNA obtained from the spore trap samples, 13 of 14 samples resulted positive to $V$. inaequalis, even with a low conidial concentration. In our study, the overall concentration estimated with a microscope count was higher than that estimated with the TaqMan qPCR assay, but with a linear relationship $\left(\mathrm{R}^{2}=0.8186\right)$. Similar results were reported by Carisse et al. (2005), pertaining to the quantification of Botrytis squamosa. However, variability in repeatability of the assay with spore trap samples seemed to have affected both the presence of falsenegatives and amplification efficiency. The reasons for the false negatives could be linked to competition in the amplification due to high amounts of nontarget DNA, inoculum density, or coextraction of contaminants (PCR inhibitors) (Bilodeau et al. 2012; Dung et al. 2015; Klosterman et al. 2014; McDevitt et al. 2007; Rogers et al. 2009; Williams et al. 2001).

In conclusion, the use of a TaqMan qPCR assay proved to be specific and highly sensitive for the detection of $V$. inaequalis, both in symptomatic and asymptomatic apple leaves and in spore trap samples. The developed assay, when combined with weather-based data models and spore traps, could be a useful tool to plan fungicide applications for apple scab management.

\section{Acknowledgments}

The authors gratefully acknowledge M. Bontà, L. Nari, and G. Vittone from AGRION for providing the samples and S. Franco Ortega for her valuable help in the development of the assay.

\section{Literature Cited}

Amaral Carneiro, G., Matić, S., Ortu, G., Garibaldi, A., Spadaro, D., and Gullino, M. L. 2017. Development and validation of a TaqMan real-time PCR assay for the specific detection and quantification of Fusarium fujikuroi in rice plants and seeds. Phytopathology 107:885-892.

Aslam, S., Tahir, A., Aslam, M. F., Alam, M. W., Shedayi, A. A., and Sadia, S. 2017. Recent advances in molecular techniques for the identification of phytopathogenic fungi-A mini review. J. Plant Interact. 12:493-504.

Baskarathevan, J., Taylor, R. K., Ho, W., McDougal, R. L., Shivas, R. G., and Alexander, B. J. R. 2016. Real-time PCR assays for the detection of Puccinia psidii. Plant Dis. 100:617-624.

Bernal-Martínez, L., Buitrago, M. J., Castelli, M. V., Rodríguez-Tudela, J. L., and Cuenca-Estrella, M. 2012. Detection of invasive infection caused by Fusarium solani and non-Fusarium solani species using a duplex quantitative PCR-based assay in a murine model of fusariosis. Med. Mycol. 50:270-275.

Bilodeau, G. J., Koike, S. T., Uribe, P., and Martin, F. N. 2012. Development of an assay for rapid detection and quantification of Verticillium dahliae in soil. Phytopathology 102:331-343.

Bilska, K., Kulik, T., Ostrowska-Kołodziejczak, A., Buśko, M., Pasquali, M., Beyer, M., Baturo-Cieśniewska, A., Juda, M., Załuski, D., Treder, K., Denekas, J., and Perkowski, J. 2018. Development of a highly sensitive FcMito qPCR assay for the quantification of the toxigenic fungal plant pathogen Fusarium culmorum. Toxins (Basel) 10:211.

Bock, C. H., Poole, G. H., Parker, P. E., and Gottwald, T. R. 2010. Plant disease severity estimated visually, by digital photography and image analysis, and by hyperspectral imaging. Crit. Rev. Plant Sci. 29:59-107. 
Bowen, J. K., Mesarich, C. H., Bus, V. G. M., Beresford, R. M., Plummer, K. M., and Templeton, M. D. 2011. Venturia inaequalis: The causal agent of apple scab. Mol. Plant Pathol. 12:105-122.

Bus, V., Rikkerink, E., Caffier, V., Durel, C., and Plummer, K. 2011. Revision of the nomenclature of the differential host-pathogen interactions of Venturia inaequalis and Malus. Annu. Rev. Phytopathol. 49:391-413.

Bustin, S. A., Benes, V., Garson, J. A., Hellemans, J., Huggett, J., Kubista, M., Mueller, R., Nolan, T., Pfaffl, M. W., Shipley, G. L., Vandesompele, J., and Wittwer, C. T. 2009. The MIQE guidelines: Minimum information for publication of quantitative real-time PCR experiments. Clin. Chem. 55:611-622.

Caffier, V., Le Cam, B., Expert, P., Tellier, M., Devaux, M., Giraud, M., and Chevalier, M. 2012. A new scab-like disease on apple caused by the formerly saprotrophic fungus Venturia asperata. Plant Pathol. 61:915-924.

Capote, N., Pastrana, A. M., Aguado, A., and Sánchez-Torres, P. 2012. Molecular tools for detection of plant pathogenic fungi and fungicide resistance. Pages 151-202 in: Plant Pathology. C. J. Cumagun, ed. InTech, Rijeka, Croatia.

Carisse, O., McCartney, H. A., Gagnon, J. A., and Brodeur, L. 2005. Quantification of airborne inoculum as an aid in the management of leaf blight of onion caused by Botrytis squamosa. Plant Dis. 89:726-733.

Carisse, O., Philion, V., Rolland, D., and Bernier, J. 2000. Effect of fall application of fungal antagonists on spring ascospore production of apple scab pathogen, Venturia inaequalis. Phytopathology 90:31-37.

Daniëls, B., De Landtsheer, A., Dreesen, R., Davey, M. W., and Keulemans, J. 2012. Real-time PCR as a promising tool to monitor growth of Venturia spp. in scabsusceptible and -resistant apple leaves. Eur. J. Plant Pathol. 134:821-833.

Deng, C. H., Plummer, K. M., Jones, D. A. B., Mesarich, C. H., Shiller, J., Taranto, A. P., et al. 2017. Comparative analysis of the predicted secretomes of Rosaceae scab pathogens Venturia inaequalis and $V$. pirina reveals expanded effector families and putative determinants of host range. BMC Genomics 18:339.

Dung, J. K. S., Scott, J. C., Alderman, S. C., Kaur, N., Walenta, D. L., Frost, K. E., and Hamm, P. B. 2015. Development of a DNA-based protocol to detect airborne ergot spores in cool-season grass seed fields. Pages 31-34 in: Seed Production Research Report at Oregon State University USDA-ARS Cooperating, Ext/CrS 152. N. P. Anderson, A. G. Hulting, D. L. Walenta, M. D. Flowers, and C. S. Sullivan, eds. Oregon State University, Corvallis, Oregon.

Ebrahimi, L., Fotouhifar, K.-B., Nikkhah, M. J., Naghavi, M. R., and Baisakh, N. 2016. Population genetic structure of apple scab (Venturia inaequalis (Cooke) G. Winter) in Iran. PLoS One 11:e0160737.

EPPO. 2014. PM 7/98 (2) Specific requirements for laboratories preparing accreditation for a plant pest diagnostic activity. EPPO Bull. 44:117-147.

Fernandez-Molina, J. V., Abad-Diaz-de-Cerio, A., Sueiro-Olivares, M., Pellon, A., Ramirez-Garcia, A., Garaizar, J., Pemán, J., Hernando, F. L., and Rementeria, A. 2014. Rapid and specific detection of section Fumigati and Aspergillus fumigatus in human samples using a new multiplex real-time PCR. Diagn. Microbiol. Infect. Dis. 80:111-118.

Franco Ortega, S., Prencipe, S., Gullino, M. L., and Spadaro, D. 2020. New molecular tool for a quick and easy detection of apple scab in the field. Agronomy 10:581.

Gadoury, D. M., and MacHardy, W. E. 1986. Forecasting ascospore dose of Venturia inaequalis in commercial apple orchards. Phytopathology 76:112-118.

Gladieux, P., Caffier, V., Devaux, M., and Le Cam, B. 2010. Host-specific differentiation among populations of Venturia inaequalis causing scab on apple, pyracantha and loquat. Fungal Genet. Biol. 47:511-521.

Gu, G., Hu, J., Cevallos-Cevallos, J. M., Richardson, S. M., Bartz, J. A., and van Bruggen, A. H. C. 2011. Internal colonization of Salmonella enterica serovar Typhimurium in tomato plants. PLoS One 6:e27340.

Gusberti, M., Patocchi, A., Gessler, C., and Broggini, G. A. L. 2012. Quantification of Venturia inaequalis growth in Malus $\times$ domestica with quantitative real-time polymerase chain reaction. Plant Dis. 96:1791-1797.

Huang, C. M., Liao, D. J., Wu, H. S., Shen, W. C., and Chung, C. L. 2016. Cyclone-based spore trapping, quantitative real-time polymerase chain reaction and high resolution melting analysis for monitoring airborne inoculum of Magnaporthe oryzae. Ann. Appl. Biol. 169:75-90.

Keitt, G. W., and Jones, L. K. 1926. Studies of the epidemiology and control of apple scab. Wisc. Agric. Exp. Stn. Res. Bull. 73:104.

Kermekchiev, M. B., Kirilova, L., Vail, E. E., and Barnes, W. M. 2009. Mutants of Taq DNA polymerase resistant to PCR inhibitors allow DNA amplification from whole blood and crude soil samples. Nucleic Acids Res. 37:e40.

Klosterman, S. J., Anchieta, A. G., McRoberts, N., Koike, S. T., Subbarao, K. V., Voglmayr, H., Choi, Y. J., Thines, M., and Martin, F. N. 2014. Coupling spore traps and quantitative PCR assays for detection of the downy mildew pathogens of spinach (Peronospora effusa) and beet (Peronospora schachtii). Phytopathology 104:1349-1359.

Koh, H. S., Sohn, S. H., Lee, Y. S., Koh, Y. J., Song, J. H., and Jung, J. S. 2013. Specific and sensitive detection of Venturia nashicola, the scab fungus of Asian pears, by nested PCR. Plant Pathol. J. 29:357-363.

Kuzdraliński, A., Kot, A., Szczerba, H., Nowak, M., and Muszyńska, M. 2017. A review of conventional PCR assays for the detection of selected phytopathogens of wheat. J. Mol. Microbiol. Biotechnol. 27:175-189.

Li, B., and Xu, X. 2002. Infection and development of apple scab (Venturia inaequalis) in old leaves. J. Phytopathol. 150:687-691.

MacHardy, W. E. 1996. Models to predict ascospore maturity.. Page 251 in: Apple Scab: Biology, Epidemiology, and Management. W. E. MacHardy, ed. American Phytopathological Society, St. Paul, MN.
MacHardy, W. E., Gadoury, D. M., and Gessler, C. 2001. Parasitic and biologica fitness of Venturia inaequalis: Relationship to disease management strategies. Plant Dis. 85:1036-1051.

Martínez, N., Martín, M. C., Herrero, A., Fernández, M., Alvarez, M. A., and Ladero, V. 2011. qPCR as a powerful tool for microbial food spoilage quantification: Significance for food quality. Trends Food Sci. Technol. 22:367-376.

McDevitt, J. J., Lees, P. S. J., Merz, W. G., and Schwab, K. J. 2007. Inhibition of quantitative PCR analysis of fungal conidia associated with indoor air particulate matter. Aerobiologia 23:35-45.

Meitz-Hopkins, J. C., von Diest, S. G., Koopman, T. A., Bahramisharif, A., and Lennox, C. L. 2014. A method to monitor airborne Venturia inaequalis ascospores using volumetric spore traps and quantitative PCR. Eur. J. Plant Pathol. 140:527-541.

Mills, W. D., and Laplante, A. A. 1951. Diseases and insects in the orchard Cornell Ext. Bull. 711:20-27.

Mirmajlessi, S., Loit, E., Mand, M., and Mansouripour, S. 2015. Real-time PCR applied to study on plant pathogens: Potential applications in diagnosis - a review. Plant Prot. Sci. 51:177-190.

Parker, D. M., Hilber, U. W., Bodmer, M., Smith, F. D., Yao, C., and Köller, W 1995. Production and transformation of conidia of Venturia inaequalis. Phytopathology 85:87-91.

Postollec, F., Falentin, H., Pavan, D., Combrisson, J., and Sohier, D. 2011. Recent advances in quantitative PCR (qPCR) applications in food microbiology. Food Microbiol. 28:848-861.

Ribbert, M., Wolters, A., Barth, S., Stoecker, M., Schaeffer, A., Fischer, R., and Finnern, R. 2007. Immunodetection of Venturia inaequalis ascospores with phage antibodies. J. Phytopathol. 155:170-177.

Rizzolli, W., and Acler, A. 2010. Prove sperimentali di difesa dalla ticchiolatura del melo. Frutta Vite. 1:13-19.

Rogers, S. L., Atkins, S. D., and West, J. S. 2009. Detection and quantification of airborne inoculum of Sclerotinia sclerotiorum using quantitative PCR. Plant Pathol. 58:324-331.

Sarkate, A., Saini, S. S., Teotia, D., Gaid, M., Mir, J. I., Roy, P., Agrawal, P. K., and Sircar, D. 2018. Comparative metabolomics of scab-resistance and susceptible apple cell cultures in response to scab fungus elicitor treatment. Sci. Rep. 8:17844

Schnabel, G., Schnabel, E. L., and Jones, A. L. 1999. Characterization of ribosomal DNA from Venturia inaequalis and its phylogenetic relationship to rDNA from other tree-fruit Venturia species. Phytopathology 89:100-108.

Schwabe, W. F. S. 1979. Change in scab susceptibility of apple leaves as influenced by age. Phytophylactica 11:53-56.

Selma, M. V., Martínez-Culebras, P. V., and Aznar, R. 2008. Real-time PCR based procedures for detection and quantification of Aspergillus carbonarius in wine grapes. Int. J. Food Microbiol. 122:126-134.

Shaw, D. V., Gordon, T. R., Hansen, J., and Kirkpatrick, S. C. 2010. Relationship between the extent of colonization by Verticillium dahliae and symptom expression in the strawberry (Fragaria $\times$ ananassa) genotypes resistant to Verticillium wilt. Plant Pathol. 59:376-381.

Sholberg, P., O'Gormann, D., Bedford, K., and Lévesque, C. A. 2005 Development of a DNA macroarray for detection and monitoring of economically important apple diseases. Plant Dis. 89:1143-1150.

Soltany-Rezaee-Rad, M., Sepehrizadeh, Z., Mottaghi-Dastjerdi, N., Yazdi, M. T. and Seyatesh, N. 2015. Comparison of SYBR Green and TaqMan real-time PCR methods for quantitative detection of residual CHO host-cell DNA in biopharmaceuticals. Biologicals 43:130-135.

Springer, J., Goldenberger, D., Schmidt, F., Weisser, M., Wehrle-Wieland, E., Einsele, H., Frei, R., and Loffler, J. 2016. Development and application of two independent real-time PCR assays to detect clinically relevant Mucorales species. J. Med. Microbiol. 65:227-234.

Stehmann, C., Pennycook, S., and Plummer, K. M. 2001. Molecular identification of a sexual interloper: The pear pathogen, Venturia pirina, has sex on apple. Phytopathology 91:633-641.

Suarez, M. B., Walsh, K., Boonham, N., O'Neill, T., Pearson, S., and Barker, I. 2005 Development of real-time PCR (TaqMan $\left.{ }^{\circledR}\right)$ assays for the detection and quantification of Botrytis cinerea in planta. Plant Physiol. Biochem. 43:890-899.

Sutton, T. B., Aldwinckle, H. S., Agnello, A. M., and Walgenbach, J. F. 2014. Page 218 in: Compendium of Apple and Pear Diseases and Pests, 2nd Ed. American Phytopathological Society, St Paul, MN

Tenzer, I., degli Ivanissevich, S., Morgante, M., and Gessler, C. 1999 Identification of microsatellite markers and their application to population genetics of Venturia inaequalis. Phytopathology 89:748-753.

Tenzer, I., and Gessler, C. 1999. Genetic diversity of Venturia inaequalis across Europe. Eur. J. Plant Pathol. 105:545-552.

Turan, C., Menghini, M., Gazzetti, K., Ceredi, G., Mari, M., and Collina, M. 2019. First identification of Venturia asperata from atypical scab-like symptoms in Italian apple orchards. E. J. Plant Pathol. 153:1325-1331.

West, J. S., and Kimber, R. B. E. 2015. Innovations in air sampling to detect plant pathogens. Ann. Appl. Biol. 166:4-17.

White, T. J., Bruns, T., Lee, S., and Taylor, J. 1990. Amplification and direct sequencing of fungal ribosomal RNA genes for phylogenetics. Pages 315-322 in: PCR Protocols: A Guide to Methods and Applications. M. A. Innis, D. H Gelfand, J. J. Sninsky, and T. J. White, eds. Academic Press, San Diego, USA.

Williams, R. H., Ward, E., and McCartney, H. A. 2001. Methods for integrated air sampling and DNA analysis for detection of airborne fungal spores. Appl Environ. Microbiol. 67:2453-2459. 